смежных дисциплин, был введен термин «лингвокультурологический» или «лингвокультурный концепт», представляющий собой условную ментальную единицу, задача которой - комплексная репрезентация сознания, языка и культуры [Зиновьева, Юрков 2006: 147].

В области лингвокультурологии концептуальный анализ считается одним из самых результативных методов. Основная единица такого анализа - лингвокультурный концепт, составляющий в совокупности концептосферу, в свою очередь, воздействующую на построение языковой картины мира конкретного этноса. $\mathrm{B}$ процессе лингвокультурологического анализа исследователь сосредоточивает внимание на уникальных, культурно-специфичных характеристиках явлений.

$$
* * *
$$

1. Аскольдов, С.А. Концепт и слово // Русская словесность. От теории словесности к структуре текста. Антология / Под общей редакцией В.П. Нерознака. - М., 1997. - С. 267-279.

2. Добросклонская, Т.Г. Медиалингвистика: системный подход к изучению языка СМИ: современная английская медиаречь: учеб. пособие / Т.Г. Добросклонская. - М.: Флинта: Наука, 2008. - 264 с.

3. Дускаева Л.Р. Медиастилистика в России: традиции и перспективы // Журналистикаи культурарусской речи. - 2011. - №58. - С. 6-26.

4. Зиновьева, Е.И., Юрков Е.Е. Лингвокультурология, учебник. - СПб.: Изд-во «Осипов», 2006. - 260 с.

5. Лихачев, Д.С. Концептосфера русского языка // Русская словесность. От теории словесности к структуре текста. $\neg$ М.: Academia, 1997. $\llcorner$ С. $280-287$.

6. Маслова, В.А. Лингвокультурология: учеб. пособие для студ. высш. учеб, заведений. - М.: Издательский центр «Академия», 2001. - 208 с.

7. Титлова, А.С. Процесс восприятия клиповой текстовой структуры: tos and pros // Языковые единицы в свете современных научных парадигм. - Уфа, 2018. - С. 161-166.

\title{
Сергеев О.А. \\ К вопросу об одном грамматическом термине в «кратком черемисском словаре»
}

Марийский научно-исследовательский институт языка, литературы и истории им. В.М. Васильева

(Россия, Йошкар-Ола)

doi: 10.18411/trnio-11-2021-204

\section{Аннотация}

Статья посвящена лингвистическому анализу одного из первых неопубликованных памятников письменности марийского языка, а именно «Краткого черемисского словаря с российским переводом...» XVIII века, хранящегося в единственном экземпляре в Отделе рукописей Российской национальной библиотеки. В работе основное внимание уделено на «цифровые» пометы 1 и 2, которые ставились составителями словаря в конце отдельных имен существительных. Эти же пометы обнаруживаем и после некоторых других частей речи. В первой марийской грамматике 1775 г. цифры 1 и 2 обозначают склонение. Ответственным за выпуск «Черемисской грамматики» термин «склонение» заимствован из Российской грамматики М.В. Ломоносова.

Ключевые слова: архивные данные, «черемисская» грамматика, лексикология, опись, протоиерей, ранний памятник письменности, рукопись, склонение, словарное дело, фонд, части речи.

\section{Abstract}

The article is devoted to the linguistic analysis of one of the first unpublished written monuments of the Mari language, namely the "Short Cheremis Dictionary with Russian translation ..." of the XVIII century, stored in a single copy in the Department of Manuscripts of the Russian National Library. The work focuses on the "digital" marks 1 and 2, which were put by the compilers of the dictionary at the end of individual nouns. The same marks are found after some other parts of speech. In the first Mari grammar of 1775, the numbers 1 and 2 denote declension. 
Responsible for the release of the "Cheremis Grammar", the term "declension" is borrowed from the Russian grammar of M.V. Lomonosov.

Keywords: archival data, "Cheremis" grammar, lexicology, inventory, archpriest, early monument of writing, manuscript, declension, vocabulary, foundation, parts of speech.

Составителями рукописного памятника марийского языка 2-й половины XVIII века являются протоиерей Кукарской слободы Троицкого собора Василий Крекнин и диакон Спасской церкви Иоанн Платунов. Полное наименование словаря состоит в следующем: «Краткой черемиской словарь съ россїйскимъ переводомъ собранный Кукарской слободы Троицкого собора Протојереемъ Василіемъ Крекнинымъ и Спаской церькви Діакономъ Јоанномъ Платуновымъ 1785 года». Ценнейший неопубликованный словарь, содержащий до 5000 лексических единиц, в единственном экземпляре хранится в Отделе рукописей Российской национальной библиотеки [4]. Сам словарь, являющийся по структуре марийскорусским, занимает 271 листов. А на 272-315 лл. приведён «Реэстръ Россійскихъ реченій изъ черемискаго словаря выбранный и по Алфавиту расположенный со означеніемъ страницъ», где после каждой русской лексемы приводится нумерация страницы, на которой данное слово находится.

Неопубликованным словарем В. Крекнина и И. Платунова в своих научных изысканиях пользовался известный финно-угровед, академик Санкт-Петербургской академии наук А.Й. Шёгрен (Andreas Johan Sjögren, 1794-1855). Переписанный им памятник (“с добавлениями и пометками А.М. Шёгрена") хранится в Архиве Санкт-Петербургского отделения Российской академии наук [13]. В частности, марийско-русский словарь большую помощь оказал А.Й. Шёгрену при составлении немецко-марийского словаря. К сожалению, это ценнейшее лексикографическое произведение XIX века также не было опубликовано. В настоящее время рукопись в одном экземпляре содержится в Архиве Санкт-Петербургского отделения РАН.

В данной работе мы остановимся на одном из особенностей подачи словарной статьи в рукописном памятнике 1785 года кукарских церковнослужителей В. Крекнина и И. Платунова. Нас интересуют цифры $\mathbf{1}$ и $\mathbf{2}$, которые поставлены составителями лексикографического произведения после большинства имен существительных (о лексической характеристике памятника см.: [9, с. 150-152]). Они по данным первой марийской грамматики обозначают склонения, в частности в «Сочиненіи принадлежащія къ грамматикъ черемискаго языка» (СПб., 1775) о них сказано: «Всђ имена Черемискїя надлежать до двухъ склоненїй, которыя различаются по окончанїю и ударенїю Именительнаго падежа» [11, с. 1]. Показателем 1-го склонения по данным грамматики 1775 года являются следующие «окончанїя»: a, я, е, и, о, у, ю, такъ же и ударяемые: é, и́, ó, ý, ю́» $[11$, с. 4]. Следует отметить то, что при составлении «Краткого черемиского словаря сь россійскимъ переводомъ...» В. Крекнин и И. Платунов руководствовались теоретическими положениями первой марийской грамматики. Об этом можно узнать из «Предисловія», включенного в рукопись лексикографического произведения [4, л. 2]. В неопубликованном памятнике цифра 1 главным образом стоит после существительных (если сочетание слов, то после второго компонента). Проиллюстрируем примеры из кукарского рукописного словаря, например: apa 1 'вино' (здесь и далее слова даны в оригинальном виде), јю 1 'сок', ланга 1 'притворство', пуро ватэ 1 'честная жена', суртанъ оза 1 'господин дому', тыгидэ кю 1 'камень, щебень', артана 1 'поленница', вашь омса 1 'двери створчетви' (ср. двери створчатые), верге 1 'почка', виса или вися 1 'пропорция, мера', шаранге или шіюртне 1 'ива', шерче 1 'ясли' и некоторые другие. Приведенный иллюстративный материал показывает, что лексические единицы оканчиваются на гласные буквы а, ю, э (е) и я, т.е. по предположению составителей памятника слова относятся к 1-му склонению.

По теоретическим положениям, разработанные в первой грамматике, следующая группа слов из крекнинского памятника также составляет 1-е склонение, ср.: вемъ 1 'мозг, мозжечок', вопшъ 1 'борт', ворь 1 'вор, хищник', вотъ 1 'снур, шнур', вургемъ 1 'одежда, 
одеяние', коль пистыль 1 'перо рыбье', межъ 1 'шерсть, волна, руно', пыланъ мардежъ 1 'пасмурная погода', агунъ 1 'овин', вицкижъ мардежъ 1 'тонкий ветер', шиль 1 'мясо' и другие. В данном случае в лексемах вемъ, вопшъ, ворь, (коль) пистыль, межъ, шиль гласные первого слога являются «ударяемыми». Составители словаря правильно отнесли эти лексические единицы к разряду 1-го склонения. В то же время после некоторых имен существительных, которые заканчиваются согласной буквой, стоит помета 1, т.е. 1-ое склонение, например: имне ша́nъ 1 'лошадь вороная', кадыръ гима́шъ (совр. мар. кагыргыммám, кадыргыма́m) 1 'кривизна', люнга́лтешъ 1 'качалка' и нек. др. Таких примеров встречается в ограниченном количестве. Приведенный иллюстративный материал не соответствует правилам первой марийской грамматики. По правилам грамматики 1775 года, как уже отметили, существительные 1-го склонения оканчиваются на гласные буквы «а, я, е,


ударной является буква $\mathbf{a}$, она не входит в рамки выделенных грамматикой букв.

По правилам первой марийской грамматики «имена втораго склоненїя вЂ Именительномъ падежъ числа Единственнаго окончательную литеру имъютъ ъ, а ударяемыя оныхъ суть только сїи три гласныя литеры á, я́, и́, въ началь или срединъ стоящїя» [11, с. 31], ср., например, словарные статьи из рукописного источника: вютъ туманъ 2 'волна водная', киндэ кюэштмашъ 2 'хлеба печение', кичалмашъ 2 'искание', коштанъ 2 'ябедник', ушмакъ 2 'безумие, глупость, глупо', шомакъ 2 'речь, прислание, слово', шональ пыль 2 'радуга', юмушто илишешамецъ 2 'небесные жители', яра жапь 2 'праздное время' и многие другие.

На наш взгляд, обозначение склонения в марийском языке связано с российской грамматикой М.В. Ломоносова. В современном русском языке имеются три склонения, кроме того, наличествуют четыре дополнительных образца склонения [см.: 10, с. 190-196]. Интересно отметить и то, что автор «Сочиненія принадлежащія к грамматикъ чувашскаго языка» [12] в чувашском языке также выделил два склонения. Как замечает А.А. Алексеев [1, c. 205; 2, с. 146, 149], к 1-му склонению отнесены имена с гласными заднего ряда, а ко 2-му имена существительные с гласными переднего ряда. В другой чувашской книге «Начертание правил чувашского языка и словарь, составленный для духовных училищ Казанской епархии» (1836) протоиерея П.И. Вишневского (П.И. Вишневецкого) [7], следуя также традиции русской грамматики, выделены три склонения. В одной из своих работ В.А. Сбоев еще в середине XIX века дал серьезную критику данной теории. В частности, он писал: «Принятое автором деление существительных имен на 3 склонения совершенно произвольно. Я думаю, что у Чуваш одно склонение. Стоит взглянуть на приведенные автором деклинационные формы, чтобы убедиться в этом. Он сделал три склонения, основываясь на различных окончаниях имен в падежах прямых. Метода слишком устарелая! Если слова в падежах косвенных имеют одинаковые окончания и разнятся только в прямых, то к какой стати тут деления на разные склонения?» [8, с. 125]. Следует констатировать то, что выпускник Казанской духовной семинарии П.И. Вишневецкий был рукоположен в сан священника с назначением в церковь святого великомученика Димитрия Солунского с. Новые Параты современного Волжского района Республики Марий Эл. Зная в совершенстве марийский язык, он активно участвовал в переводе церковных книг на луговое наречие [14, c. $62 ; 3$, с. 162-163]. Так же им был составлен «черемисский букварь», но, по словам его сына, уроженца села Параты Казанского уезда Казанской губернии (сам он пишет «...что я родом из черемисского села...»), выпускника Казанской духовной академии 1872 года Н.П. Вишневецкого, «к сожалению, материал, приготовленный им (П.И. Вишневецким - О.С.), оказался малопригодным по содержанию переведенных статей...» [5, л. 220-220 об.]. Впоследствии Н.П. Вишневецкий сам «задумал привести в исполнение заветное желание покойного отца» своего. Труд под названием «Черемисская грамота» он окончил «к 15 июня и отправил в черне к попечителю на его усмотрение...» [5, л. 220 об.]. Об этом стало известно из письма Николая Павловича, отправленного 23 августа 1879 года из Башкирии директору Казанской учительской (инородческой) семинарии Н.И. Ильминскому [5, л. 219; также см.: 6, л. 23 об.]. 
Нельзя не отметить и то, что в крекнинском рукописном словаре после некоторых имен существительных не отмечено склонение, например: нуранъ 'севрюга', палачь 'заплечной мастер, палач', регензе 'мох', таратемашъ 'возбуждение' и некоторые другие. По правилам первой грамматики, лексемы нуран, палач, таратымаш должны были относиться ко 2-му склонению, а лексическая единица регенче - к 1-му склонению. В грамматике 1775 г. отмечено, что категорию склонения имеют только имена существительные. Однако материалы рукописного памятника 1785 г. содержат грамматическую помету склонение и после других частей речи. Таковыми являются: имена прилагательные, например: віашъ 2 'простота, постоянство, справедливость, правдивый, искренний', кюжго 1 'толстый', лушкудо 1 'слабый, слабкий, слабость', мутанъ 2 'краснословный, краснослов', мюндурь 1 'далекость, дальность', осаль 2 'зло, плут', у 1 'новость, новый', чаплэ 1 'превосходство', шакше 1 'гнусность, не чистота, не чисть', шигирь 1 'теснота, тесно', юктумо 1 сипота; наречия: вашкеракъ 'предускорение', кюшке 1 'верх' и некоторые другие; причастия: вюдуме 1 'засеянный'; послеложные конструкции: вюргене геценъ 1 'доска из меди или железа', јоль ималь 2 'подножие'. В справедливости можно сказать, что многие марийские слова на русский язык переведены как имена существительные. Интересно отметить то, что в рукописных словниках участников Камчатских экспедиций Г.Ф. Миллера и И.Э. Фишера, также в словариках, подготовленных для сравнительных словарей П.-С. Палласа, указание на склонение отсутствует. Пометы 1 и 2 также не фигурируют в неопубликованных словарях Д. Дамаскина и в анонимном «Словаре Языка Черемискаго», относящихся ко второй половине XVIII столетия.

Подробно анализируя неопубликованный памятник марийского языка 236-летней давности, можно отметить, что пометы 1 и 2 В. Крекниным и И. Платуновым заимствованы из «Сочиненія принадлежащиія к грамматикъ черемискаго языка». Ответственный за выпуск этой книги, плохо знавший морфологию марийского языка, ошибочно заимствовал термин склонение из грамматики русского языка.

$$
\text { *** }
$$

1. Алексеев А.А. Заметки о первых грамматических трудах по чувашскому языку // Ученые записки. Выпуск 49. Филология. Чебоксары, 1970. С. 203-221.

2. Алексеев А.А. Первые печатные грамматики чувашского языка как памятник письменности // 200 лет марийской письменности / Материалы научной сессии. Йошкар-Ола: МарНИИ, 1977. С. 144-151.

3. Ерошкин Ю.В. Вишневецкий Павел Иванович (1813-1869) // История Марийского края в лицах. XIV начало ХХ веков. Йошкар-Ола: МарНИИЯЛИ, 2012. С. 162-164.

4. Краткой Черемиской словарь съ россійскимъ переводомъ собранный Кукарской слободы Троицкого собора Протојереемъ Василіемъ Крекнинымъ и Спаской церькви Діакономъ Јоанномъ Платуновымъ 1785 года. Эрм. собр. № 197/1.

5. Национальный архив Республики Татарстан. Ф. 93, оп. 1, д. № 23. Переписка директора семинарии с миссионерами. 234 л.

6. Национальный архив Республики Татарстан. Ф. 968, оп.1, д. № 89. Письма Н.И. Ильминскому. 41 л.

7. Начертание правил чувашского языка и словарь, составленные для духовных училищ Казанской епархии. Казань: Типогр. университета, 1836.

8. Сбоев В.А. Заметки о чувашах. Чебоксары: Чуваш. кн. изд-во, 2004. 142 с.

9. Сергеев О.А. О лексике «Краткого черемисского словаря с российским переводом...» // Филологические науки. Вопросы теории и практики. Научно-теоретический и прикладной журнал. № 12 (42) 2014. Часть II. Тамбов: Грамота, 2014. С. 150-152.

10. Современный русский литературный язык: Учеб. для филол. спец. пед. ин-тов / П.А. Лекант, Н.Г. Гольцова, В.П. Жуков и др.; под ред. П.А. Леканта. - 2-е изд., испр. М.: Высш. шк., 1988. 416 с.

11. Сочиненія принадлежащиія к грамматикъ черемискаго языка. Въ Санкт-Петербургъ при Императорской Академіи наукь 1775 года. 136 с.

12. Сочинения принадлежащія к грамматикъ чувашскаго языка. Въ Санкт-Петербургъ при Императорской Академіи наукъ 1769 года. 69 с.

13. Ф. 94, оп. 1, ед. хр. 233, фонд Шёгрена // Архив Санкт-Петербургского отделения Российской академии наук.

14. Эман С.И. Дореволюционные письменные памятники на марийском языке. Введение // Труды МарНИИСК. Вып. І. Вопросы языка, литературы, фольклора и истории мари. Козьмодемьянск: Горномарийский филиал Мар. гос. изд-ва, 1939. С. 42-62. 